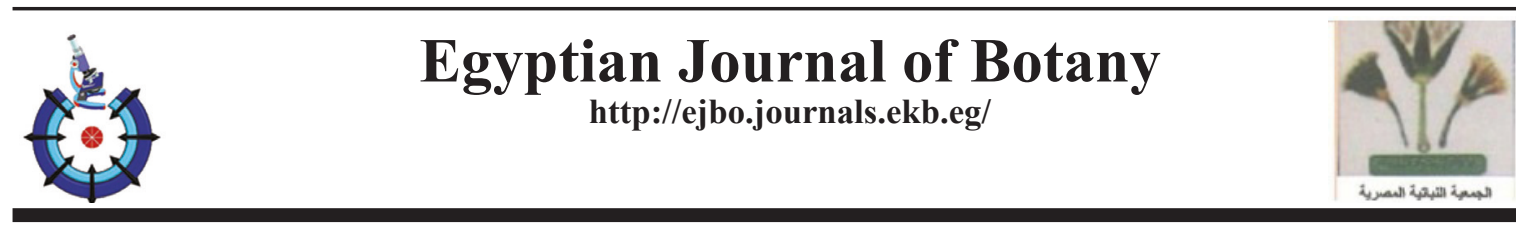

\title{
Pollen Morphology and Generic Delimitation of the Polygonaceae in Egypt
}

\author{
Mona Adel Shiha \\ Biology and Geology Department, Faculty of Education, Alexandria University, Egypt
}

\begin{abstract}
DOLlEN grains of 18 species representing seven genera (Atraphaxis, Calligonum, Oxygonum, Emex, Periscaria, Polygonum and Rumex) of Polygonaceae Juss. (Subfamily, Polygonoideae) in Egypt were investigated using light microscopy (LM) and scanning electron microscopy (SEM) to evaluate the taxonomic value of micro-morphological characters of pollen grains in order to differentiate between the genera and species. The study showed that pollen grains are radially symmetrical, isopolar, oblate-spheroidal, spheroidal, subprolate to prolate, with ambtrilobed or circular, tricolporoidate, tricolporate, rarely tetracolporate and pantopolyporate. Tectum is striato-reticulate to reticulate, coarse reticulate with double bacula in muri and pilatelumine, rugulo-reticulate, microechinate-foveolate, and microgranulateperforate Based on these characters, five groups of pollen types are recognized. The results indicate that pollen morphology characters of shape, aperture and exine ornamentation are useful in generic delimitation. A key for the separation of the different pollen types is provided.
\end{abstract}

Keywords: Generic delimitation, Pollen morphology, Polygonaceae, Polygonoideae, SEM.

\section{Introduction}

The Polygonaceae Juss., are a cosmopolitan family of herbs, shrubs and small trees characterized by simple leaves with sheathing ochreastipules (Ronse Decraene \& Akeroyd, 1988; Li et al., 2003; Sanchez \& Kron, 2008). It comprises about 59 genera embracing 5,385 species (The Plantlist.org, 2018). According to Boulos (1999), the Polygonaceae are represented in Egypt by 29 species belonging to eight genera.

The classification of Polygonaceae was a matter of debate at the generic and tribal levels since the $19^{\text {th }}$. century (Haraldson, 1987; Ronse Decraene \& Akeroyd, 1988). The family was divided into three subfamilies on the basis of morphological evidences (Dammer, 1892; Gross, 1913; Roberty \& Vautier, 1964). More recently, Freeman \& Reveal (2005) and Burke et al. (2010), recognized two subfamilies (Eriogonoideae and Polygonoideae) on the basis of other criteria. Several studies dealt with the macro- and micro-morphological characters of Polygonaceae (Simmonds, 1945; Haraldson, 1987; Ronse Decraene \& Akeroyd, 1988; Hamed \& Tantawy, 1990, 1991; Leresten \& Curtis, 1992; Brandbyge, 1993; Partridge, 2001; Li et al., 2003; Tantawy et al., 2005; Mosaferi \& Keshavarzi, 2011; Hussein et al., 2012). The Polygonaceae are a europalynous family among dicotyledons (Wodehouse, 1931). The pollen morphology and taxonomy of Polygonaceae were the subject of several studies (e.g. Gross, 1913; Wodehouse, 1931; Hedberg, 1946; Nowicke \& Skvarla, 1977).

The objective of the study is to examine and shed more light on the pollen morphological characters in the family as well as to assess the significance of the pollen characters in the delimitation of genera and species.

\section{Materials and Methods}

Pollen grains samples of 18 species belonging to seven genera of the Polygonaceae- 
Polygonoideae were collected from their natural habitats or specific herbaria (Table 1). Materials for light microscope were prepared according to Erdtmann (1960). At least 30 pollen grains per taxon were examined by using Zeiss light microscope with an eye-piece micrometer. For SEM studies, non-acetolyzed grains were mounted on aluminum stubs, with double sided adhesive tape, coated for $5 \mathrm{~min}$ with a thin layer of gold in a JFC-1100E ion sputtering coating unite, examined at accelerating voltage of $15-25 \mathrm{KV}$. and then photographed with JEOL JSM- 5300 SEM (Electron Microscopic Unit, Faculty of Science, Alexandria University). The terminology used here for pollen description is in accordance with Erdtman (1952) and Punt et al. (2007).

TABLE 1. Collection data of the specimens representing 18 species from 7 genera of the Polygonaceae.

\begin{tabular}{|c|c|}
\hline Calligonum comosum L'Hér. & Museum Wadi el Rayan, 20/42008/, Mona Shiha, ALEX. \\
\hline Emex spinosa (L.) Campd. & Matrouh, 312005/3/, Sania Kamal, ALEX. \\
\hline Oxygonum sinuatum (Meisn.) Dammer & Khar Gwob Red sea, 1066/12/, L. Boulos, Boulos Herb. \\
\hline Persicaria lapathifolia (L.) Delarbre & Lake Edku, 182003/4/, Tarek Galal, Tanta Herb. \\
\hline Persicaria salicifolia (Brouss. Ex Willd) Assenov & $\begin{array}{l}\text { Edku Lake, 45km before Edku Agnic. Secondary School, } \\
\text { 152008/12/, Ream Marzouk \& Samia Rashad, ALEX. }\end{array}$ \\
\hline Persicaria senegalensis (Meisn.)Soják & $\begin{array}{l}\text { Masraf el Gabaroti, Mohatta El-Aslah on the road Alex.- } \\
\text { Rosetta,81970/9/, R. El-Ghareeb, ALEX. }\end{array}$ \\
\hline Polygonum aviculare L. & Mersa Matrouh, 20/4/2006, L. Boulos, Boulos Herb. \\
\hline Polygonum plebeijum R. Br. & Mersa Matrouh, 31994/, Dr. Maged, ALEX. \\
\hline Rumex bucephalophorus L. & Elsalom Plateau, 3/78, L. Boulos, Boulos Herb. \\
\hline Rumex cyprius Murb. & Sinai, 295/4/, Sania Kamal, M. Fawzy, ALEX. \\
\hline Rumex dentatus L. & Burg El- Arab, 25/ 32017/, M. Shiha, ALEX. \\
\hline Rumex pictus Forssk. & El Omaid, 878/3/, L. Boulos, Boulos Herb. \\
\hline Rumex vesicarius $\mathrm{L}$. & $\begin{array}{l}\text { Wadi El-Ghadir, 41961/2/, Vivi Täckholm, M. Kassas, M. Samy, } \\
\text { CAI. }\end{array}$ \\
\hline
\end{tabular}




\section{Results}

Variation in pollen morphological characteristics as revealed by LM \& SEM is presented in Table 2 and illustrated by SEM micrographs in Figs. 1-36. Five pollen types are easily recognizable in the following key:

1a. pollen grains polypantoporate..... Persicariatype

1b. Pollen grains 3-4 colporate. .2

2a. Pollen grains oblatespheroidal............................mex-Rumex type

2b. Pollen grains prolate to subprolate 3

3a. Tectum microechinate foveolate......................................Polygonum type

3b. Tectumrugulo-microreticulate to reticulate .......................... alligonum-Oxygonum type

3c. Tectum striate-reticulate ...... Atraphaxistype

There follows a detailed description of the five pollen types with names of taxa characterized by each type.

1- Atraphaxis type: Pollen grains isopolar, radiosymmetric, tricolporate, prolate; Polar axis $(\mathrm{P})=11.73-13.84 \mu \mathrm{m}$, Equatorial diameter $(\mathrm{E})=$ 7.69-8.26 $\mu \mathrm{m}, \mathrm{P} / \mathrm{E}=1.5-1.7$. Ambtrilobed.Colpi length $(\mathrm{L})=10.57-11.92 \mu \mathrm{m}$, slit-like, narrow, distinctly sunken, ends acute, ora usually not distinctly delimited, lalongate. Exine sculpture striate-reticulate, the striae running parallel to the colpus. This pollen type characterizes Atraphaxis spinosa. (Figs. 1, 2).

2- Calligonum and Oxygonum type: Pollen grains isopolar, radiosymmetric, tricolporate,

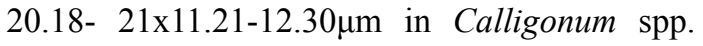
and $26.66 \times 12.85 \mu \mathrm{m}$ in Oxygonum sinuatum. Pollen shape prolate, $\mathrm{P} / \mathrm{E}=1.6-1.9$ with trilobed amb. Ectoaperture colpus, narrow, slit-like, long, sunken, with acute ends. Endoaperture porus, lolongate. Exine sculpture rugulo microreticulate to reticulate. This type characterizes three species: Calligonumcomosum,Calligonum polygonoides (Figs. 3-6) and Oxygonum sinuatum (Figs. 7 and 8).
3- Persicaria type: All Persicaria spp. have this type of grains. Pollen grains isopolar, radiosymmetric, pantoporate, with average diameter in the range of $15.62-42.0 \mu \mathrm{m}$. Spheroidal in shape $\mathrm{P} / \mathrm{E} \pm 1$. Grains of Persicaria salicifolia $(15.62 \mu \mathrm{m})$ appeared to be the smallest in diameter while those of $P$. lanigera $(42 \mu \mathrm{m})$ are the largest. $P$. senegalensis $(18.75 \mu \mathrm{m})$ and $P$. lapathifolia $(27.1 \mu \mathrm{m})$ grains are intermediate in size. Exine sculpture clearly visible in the four Persicaria species, tectum appeared coarse reticulate in pattern. Pori circular, distributed in a single lumen of the reticulum, lumina variable in size, angular, usually forming 4-6 sided polygonal, the sides straight to slightly wavy, granules numerous inside the lumina. Muri thin dupli-columellate, columella usually opposite or alternate.(Figs. 9-16).

4- Polygonum type: All Polygonum investigated species have this type of grains. Pollen grains are isopolar, radiosymmetric, tricolporate, pollen size varies from $10.95-26.5 \mathrm{x}$ $7.89-13.5 \mu \mathrm{m}$. Polygonum bellardii (10.95x $8.45 \mu \mathrm{m})$ appears to be smallest in size, while $P$. equisetiforme $(27.1 \mathrm{x} 13.5 \mu \mathrm{m})$ has the maximum size among the studied species. Subprolate to prolate, $\mathrm{P} / \mathrm{E}=1.29-1.91$, fossaperturate amb. Aperture ectoaperture colpus, narrow, slit-like, long and sunken, with acute ends. Endoaperture pore lolongate. Exine sculpture micro echinatefoveolate tectum (Figs. 17-24).

5- Rumex and Emex type: Pollen grains are isopolar, radiosymmetric, oblate spheroidal to subprolate in shape $\mathrm{P} / \mathrm{E}=0.93-1.4$, circular to quadangular in polar view. Apertures 3-4, colporate in Rumex dentatus, tricolporoidate in Rumex cyprius; tricolporate in $R$. bucephalophorus, $R$. pictus and $R$. vesicarius and 3-brevicolpate in Emex spinosa. Ectoaperture colpus, narrow, long, usually sunken, with acute ends in Rumex, while narrow, very short in Emex spinosa. Endoaperture porous, lalongate or \pm lolongate. Exine sculpture granular-microgranulate, perforated tectum in the investigated Rumex spp. and microreticulatefoveolate with granules (spinules) on the surface in Emex spinosa, Rumex bucephalophorus, $R$. cyprius, $R$. dentatus, $R$. pictus and $R$. vesicarius. Based on variation in the pollen micro-morpholgical characters, an artificial key was constructed to facilitate the discrimination between the five pollen types. 


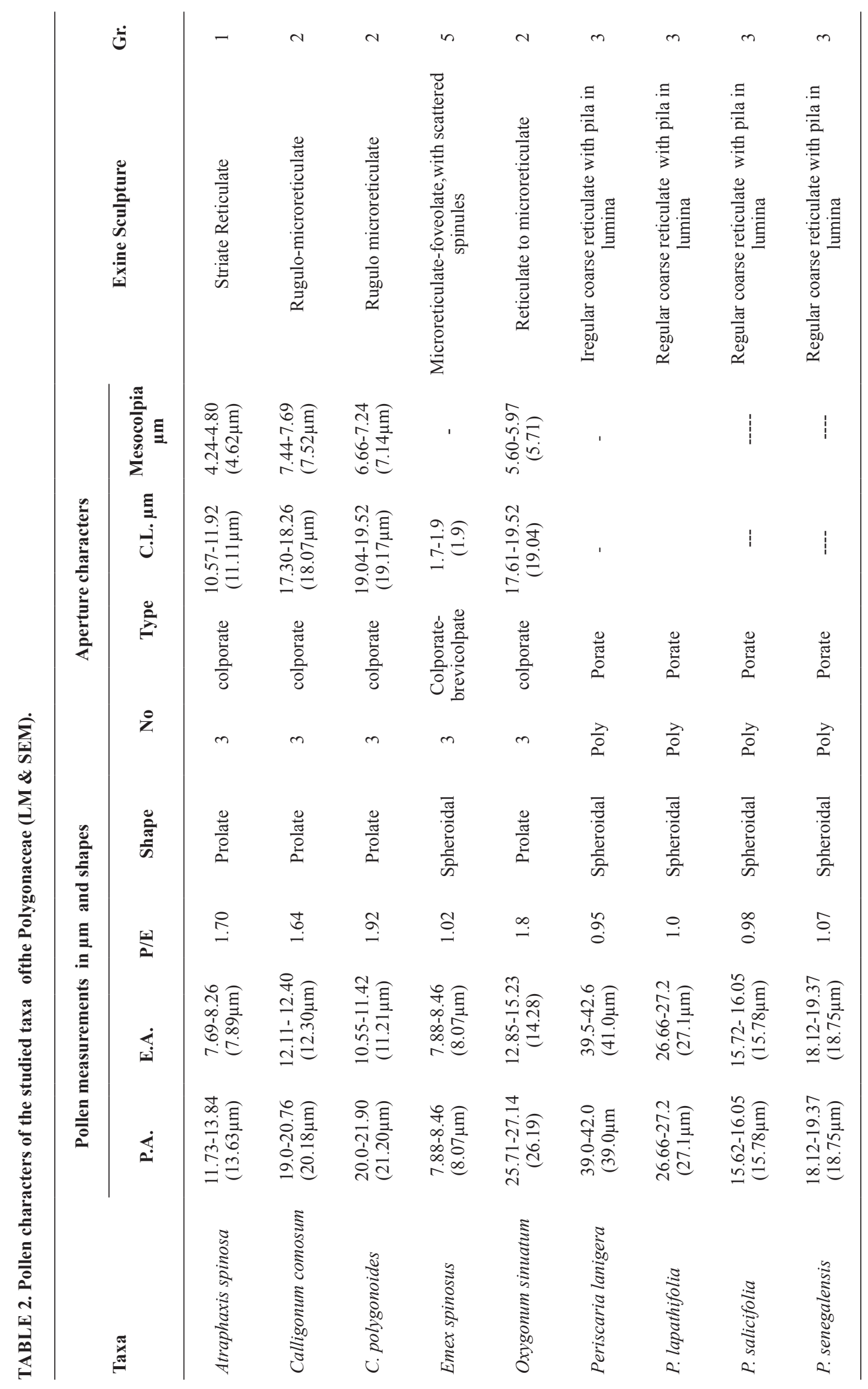

Egypt. J. Bot. 60, No. 2 (2020) 


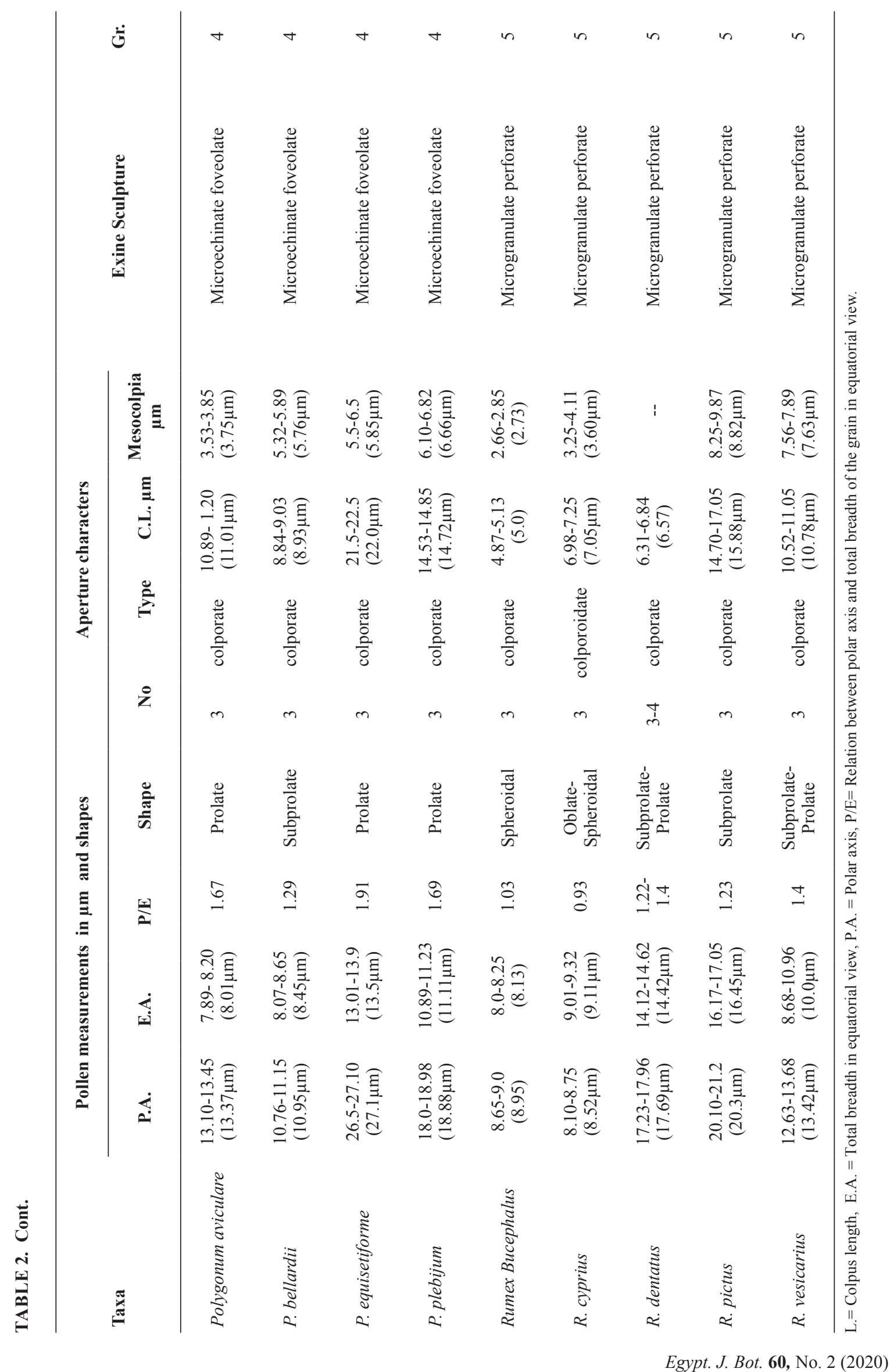



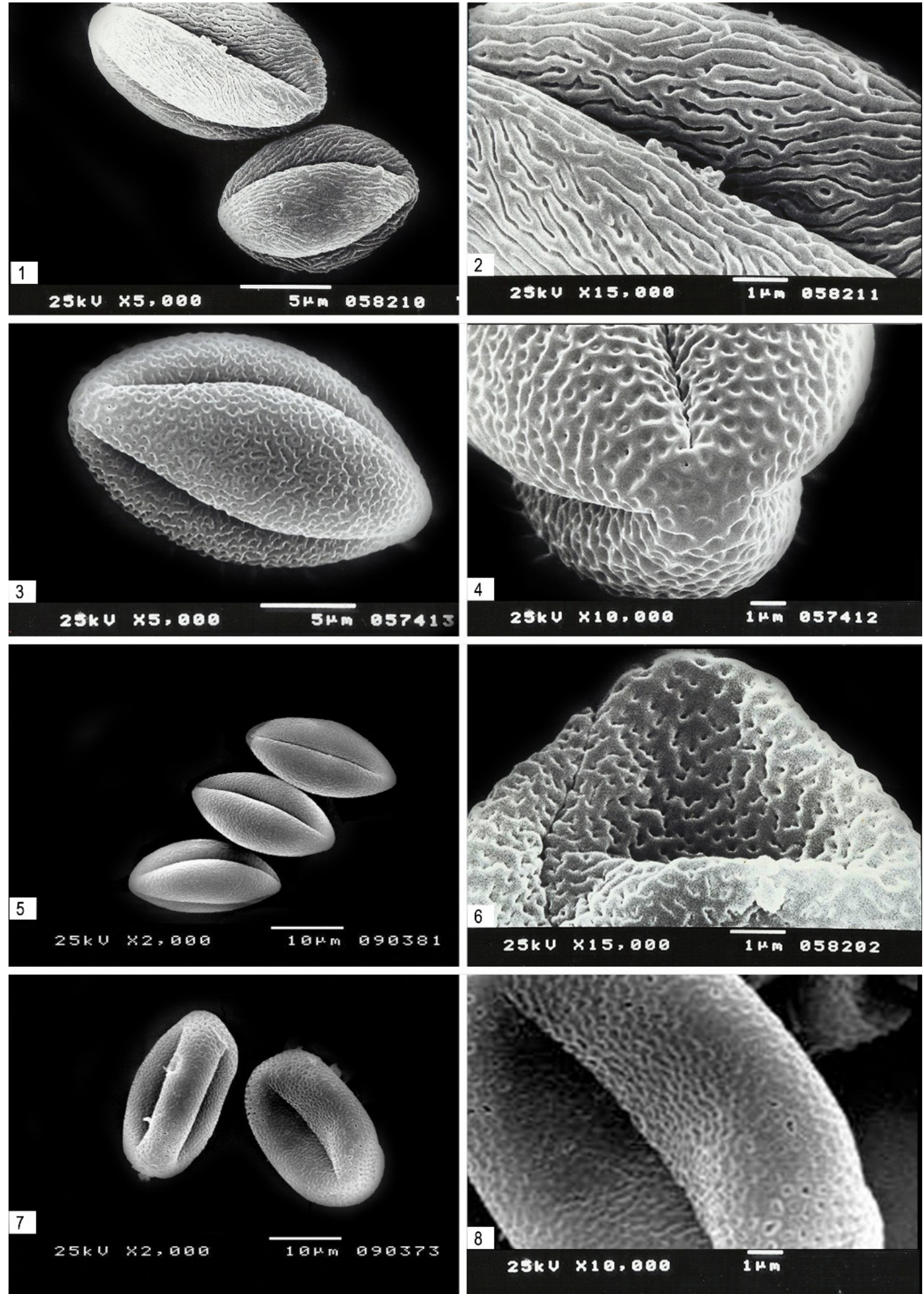

Figs. 1-8. SEM micrographs of pollen grains.
$(1,2)$ Atraphix spinose
$(3,4)$ Calligonum comosum
$(5,6)$ Calligonum polygonoides
$(7,8)$ Oxygonum sinuatum

Egypt. J. Bot. 60, No. 2 (2020) 

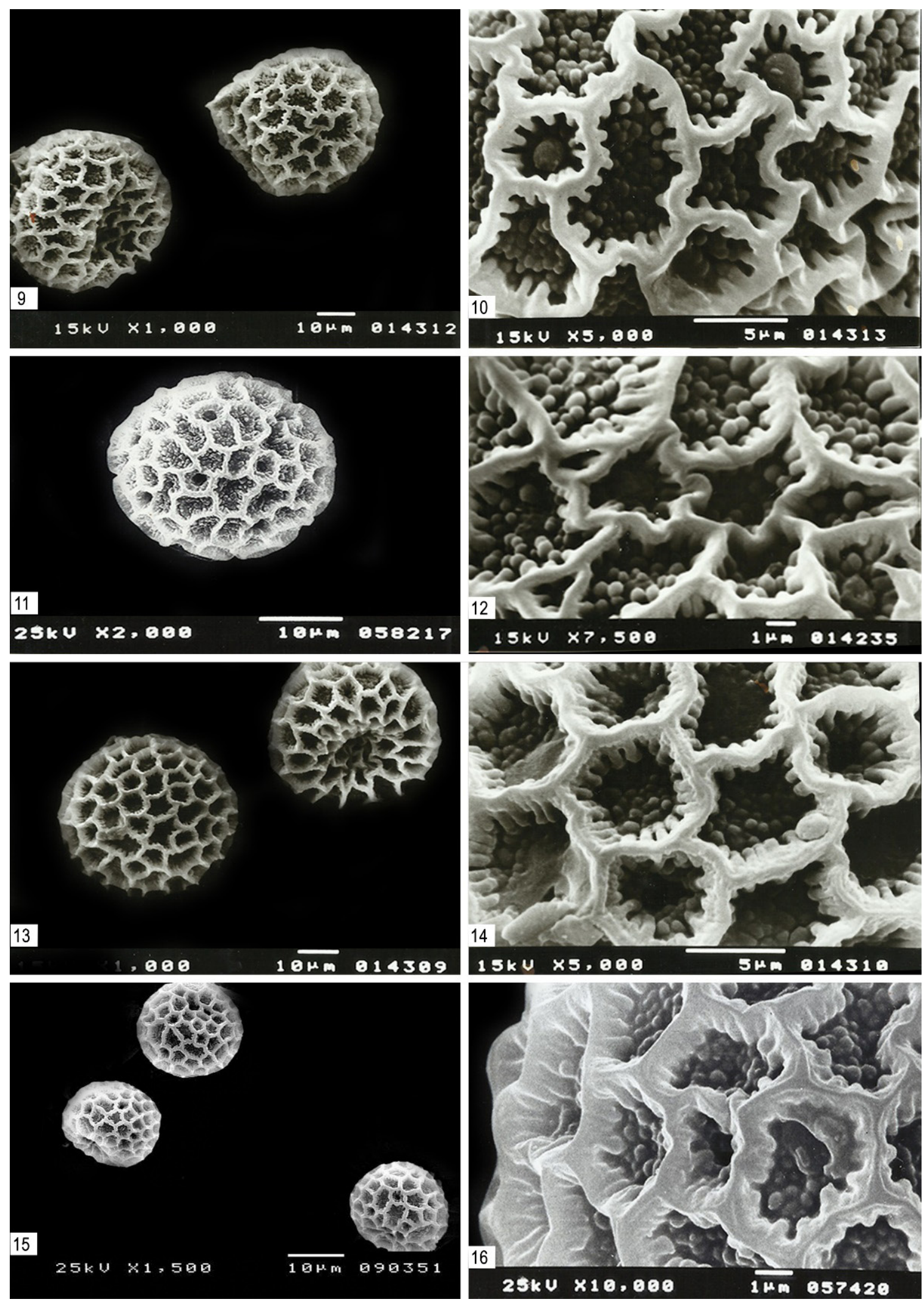

Figs. 9-16. SEM micrographs of pollen grains.
$(9,10)$ Periscaria lapathifolia
$(11,12)$ P. longeria
$(13,14)$ P. senegalensis
$(15,16)$ P. salicifolia 

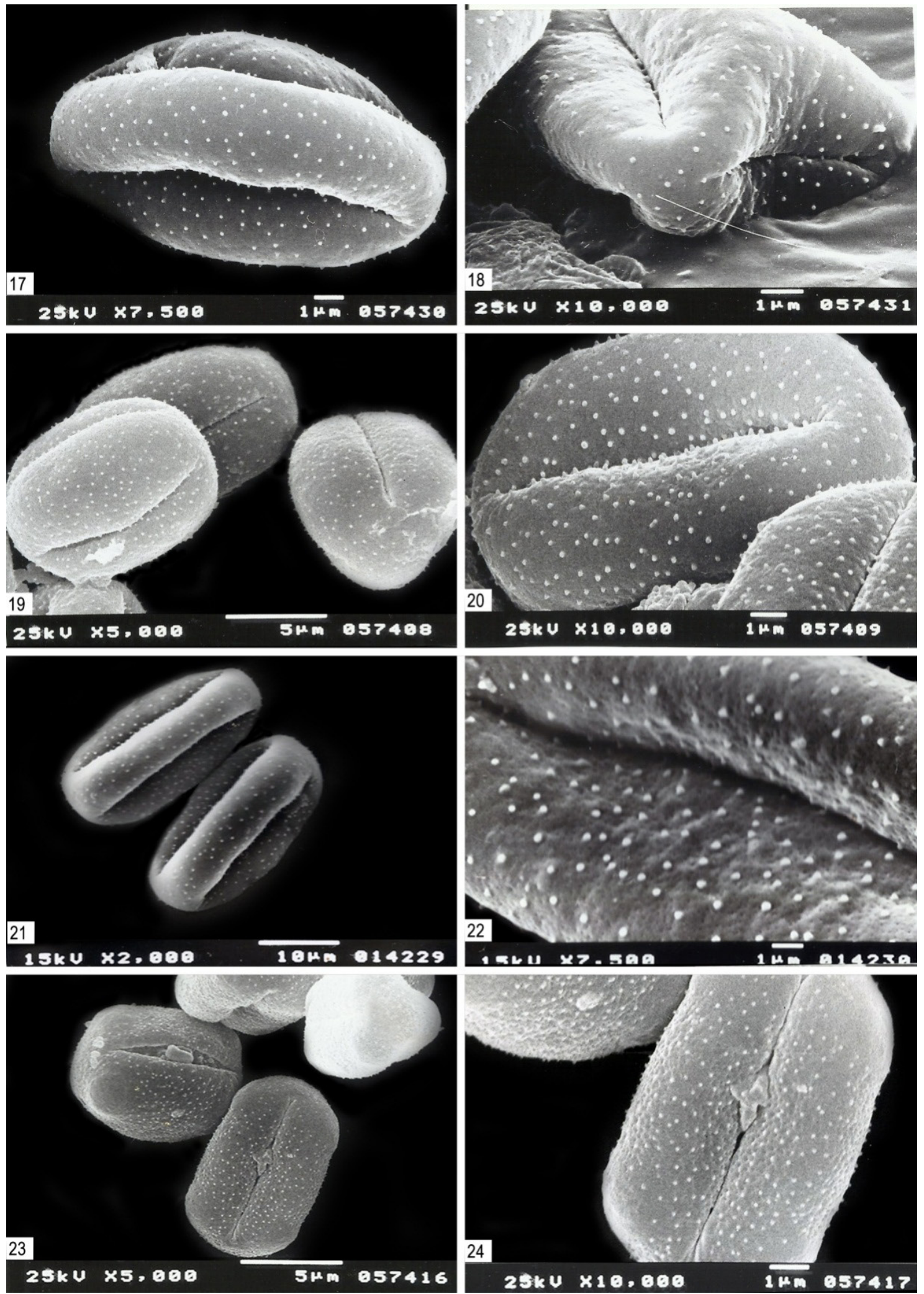

Figs. 17-24. SEM micrographs of pollen grains.

(17-18) Polygonum auvicular

(21-22) P. equistiform
(19-20) P. bellarii

(23-14) P. plebijum 

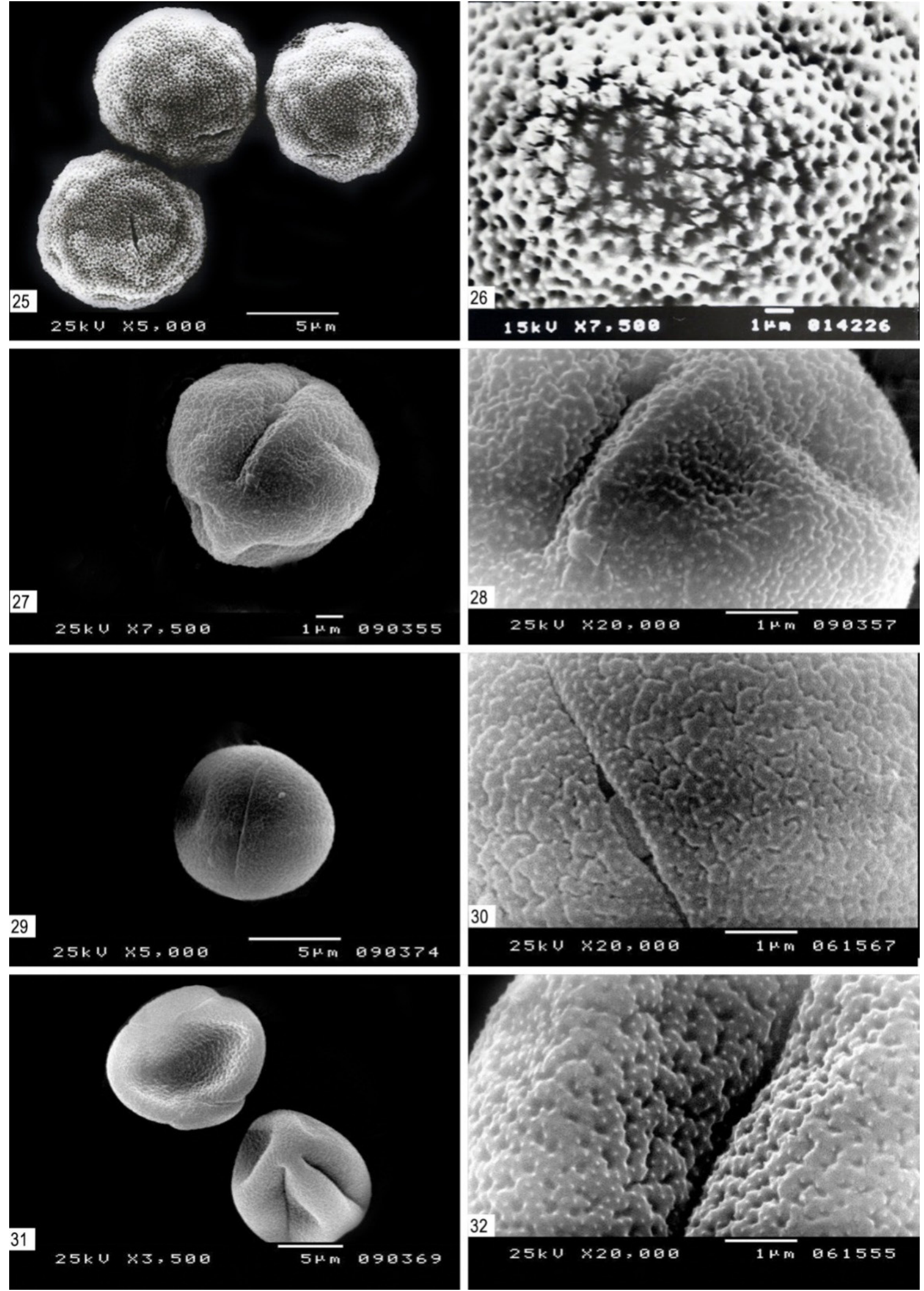

Figs. 25-32. SEM micrographs of pollen grains.

(25-26) Emex spinosa

(27-28) Rumex bucephalus

(29-30) R. cyprius

(31-32) R. dentatus 

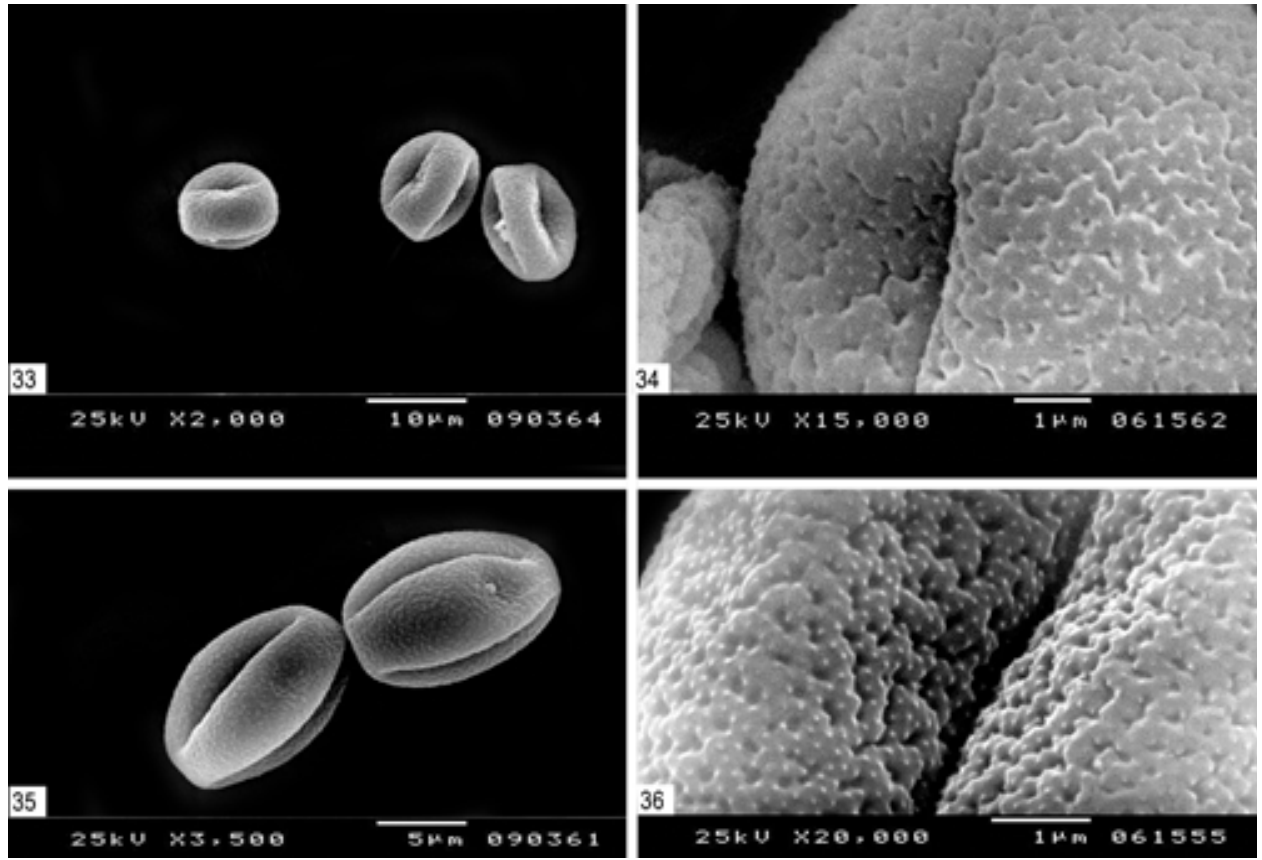

Figs. 33-36. SEM micrographs of pollen grains.

\section{Discussion}

The Polygonaceae are evidently an europalynous family. Theirpollen morphological characters were successfully used in the taxonomy of the family, especially at generic level (Nowicke \& Skvarla, 1977; Van Leeuwen et al., 1988; Yurtseva, 2014, 2016).

The striate-reticulate exine sculpture is unique to Atraphaxis spinosa and was not encountered in any of the other 17 species in the present study or in the whole family (Nowicke \& Skvarla, 1977, 1979). This result is in agreement with Yurtseva et al. (2014) who examined pollen morphology of 23 Atraphaxis spp. According to Bao \& Li (1993) and Hong (1995), the striate ornamentation of pollen exine in Atraphaxis is different from other patterns of ornamentation recorded in the rest of the family.

The Calligonum-Oxygonum type is characterized by two patterns of exine ornamentation: rugulo-microreticulate in Calligonum species. Hong (1995), studying pollen morphology of Calligonum comosum and $C$. polygonoides beside other taxa of Polygonaceae, reported similar type of pollen surface. Nevertheless, the present finding regarding the Calligonum species is not in agreement with Nair et al. (1976), since he described the pollen grains of Calligonum species as "3-zonocolpate with reticulate exine". The reticulate to microreticulate pattern is found in Oxygonum sinuatum. ElNaggar \& El-Husseini (2001), studying pollen morphology of Polygonaceae, reported the same pollen type in the genus Oxygonum.

Palynological evidence from the present study indicates the naturalness of Persicaria spp. with their spheroidal poly-pantoporate grains, coarsely reticulate tectum with regularly distributed hexagonal lumina filled with free bacula. The Persicaria pollen type was also reported by Wodehouse (1931), Hedberg (1946), Perveen (1993), Yasmin et al. (2010), and Mosaferi \& Keshavarzi (2011).

The Polygonum type of tricolporate pollen with microechinate-foveolate surface was present in all the studied species of Polygonum. This pollen type is comparable to the avicularia type proposed previously by Wang \& Feng (1994), Zhang \& Zhou (1998) and Hong et al. (2005).

The Rumex-Emex type is the characteristic feature of Rumex spp. and Emex spp. Pollen shape varied from oblate spheroidal to subprolate. The grains are tricolporate in $R$. bucephalophorus, R. pictus and $R$. vesicarius, tricolporoidate in Rumex cyprius, tri- tetra- 
colporate in Rumex dentatus with microgranulateperforate tectum. The present observation is similar to that of Zhang \& Zhou (1998), Wodehouse (1931) concerning the distribution of apertures and exine sculpture. However, the present finding disagrees with Perveen (1993), who described pollen grains of Rumex dentatus as pantocolporate.

\section{Conclusion}

Based on the present study, it would appear that there is quite considerable variation in pollen micromorphology characters especially as shape, aperture types and number as well as exine ornamentation that make the pollen grains of systematic value and a distinct structure which can be employed for the delimitation of the genera in the Polygonaceae.

\section{Reference}

Bao, B.J., Li, A.R. (1993) A study of the genus Atraphaxisin China and the system of Atraphaxideae (Polygonaceae). Acta Phytotaxonomica Sinica, 31, 127-139.

Boulos, L. (1999) "Flora of Egypt", Vol. 1.AzollaceaeOxalidaceae. Al Hadara Publishing, Cairo.

Brandbyge, J. (1993) Polygonaceae. In: "The Families and Genera of Vascular Plants", Kubitzky, K., Rohver, J.G., Bittlich, V. (Eds.), pp. 531-544, $2^{\text {nd }}$ ed. Berlin.

Burke, J.M., Sanchez, A., Kron, K., Luckow, M. (2010) Placing the woody tropical genera of Polygonaceae: A hypothesis of character evolution and phylogeny. American Journal of Botany, 97, 1377-1390.

Dammer, U. (1892) Polygonaceae. In: A. Engler und K. Prantl, Die natürlichen Pflanzenfamilien, 1(1a): 1-36. Leipzeig.

El-Naggar, S.M., El-Husseini, N. (2001) "Pollen Atlas of the Flora of Egypt". 2. Species of Polygonaceae. Täeckholmia, 21(1), 143-151.

Erdtman, G. (1952) Pollen morphology and Plant Taxonomy (An introduction to Palynology-1, Angiosperm). Almqvist and Wiksell, Stockholm.

Erdtmann, G. (1960) The acetolysis method: A revised description. Svensk Botanisk Tidskrift. 54, 561-564.

Freeman, C.C., Reveal, J.L. (2005) Polygonaceae.Vol.
5. "Flora of North America". Oxford University Press, pp. 216-218.

Gross, H. (1913) Beiträgezur Kenntnis der Polygonaceen. Botanisch Jahrbücher Für Systematik, 49(2), 243-348.

Hamed, K.A., Tantawy, M.E. (1990) The stem anatomy of some Polygonaceae and its diagnostic significance in identification. Journal Faculty of Education, 15, 249-268.

Hedberg, 0. (1946) Pollen morphology in the genus Polyggonum L. s.l. and its taxonomical significmce. - Svensk Botanisk Tidskrift, 40, 371-404.

Hong S.-P. (1995) Pollen morphology of Parapteropyrum and some putatively related genera (Polygonaceae- Atraphaxideae). Grana, 34, 153-159.

Hong, S-P., Oh, I-C., Ronse De Craene, L-P. (2005) Pollen morphology of the genera Polygonum s.str. and Polygonella (Polygoneae: Polygonaceae). Plant Systematics and Evolution, 254(1-2), 13-30. DOI 10.1007/s00606-005-0334-4.

Hussein, S., El-Magly, U., Tantawy, M., Kawashty, S., Saleh, N. (2012) Phenolics of selected species of Persicaria and Polygonum (Polygonaceae) in Egypt. Arabian Journal of Chemistry, 62(1). http:// dx.doi.org/10.1016/j.arabjc.2012.06.002

Leresten, N.R., Curtis, J.D. ( 1992) Foliar anatomy of Polygonum (Polygonaceae): Survey of epidermal and selected internal structures. Plant Systematics and Evolution, 182, 71-106.

Li, A.J., Bao, B., Grabovskaya-Borodina, A.E., Hong S-P., McNeill, J., Mosyakin, S.L., Ohba, H., Park, C-W. (2003) Polygonaceae. In: "Flora of China", Wu, Z.Y., Raven P.H., Hong, D.Y. (Eds.), Vol. 5, pp. 277-350, Beijing: Science.

Mosaferi,S.,Keshavarzi,M.(2011)Micromorphological study of Polygonaceae tribes in Iran. - Phytologia Balcanica, 17(1), 89-100.

Nair, P.K.K., Rehman, K., Saxena, A.K. (1976) Contribution to the pollen morphology of Indian Polygonaceae. Journal of Palynology, 12, 1-18.

Nowicke, J.W., Skvarla, J.J. (1977) Pollen morphology and the relationship of the Plumbaginaceae, 
Polygonaceae, Primulaceae to the order Centrospermae. Smithsonian Contribution of Botany, 37, 1-64.

Nowicke J.W., Skvarla, J.J. (1979) Pollen morphology: The potential influence in higher order systematics. Annals Missouri Botanical Garden, 66, 633-700.

Partridge, J.W. (2001) Persicaria amphibia (L.) Gray (Polygonum amphibium L.). Journal of Ecology, 89, 487-501.

Perveen, A. (1993) A preliminary study of the pollen flora of Karachi.Ph.D Thesis. University of Karachi, Karachi.

Punt, W., Hoen, P.P., Nilsson, S., Thomas, L. (2007) Glosssary of Pollen and Spore Terminology. Review of Paleobotany and Palynology, 143, 1-81.

Roberty, G., Vautier, S. (1964) Les genres de Polygonace'es. Boissiera, 10, 7-128.

Ronse Decraene, L.P., Akeroyd, J.R. (1988) Generic limits in Polygonum L. and related genera (Polygonaceae) on the basis of floral characters. Botanical Journal of the Linnean Society, 98, 321371.

Sanchez, A., Kron, K.A. (2008) Phylogenetics of Polygonaceae with an emphasis on the evolution of Eriogonoideae. Systematic Botany, 33, 87-96.

Simmonds, N.W. (1945) Polygonum persicaria L. Journal of Ecology, 33, 121-131.

Tantawy, M.E. (1991) The microcharacters of the petiole and blade of certain Polygonaceae as an identificatory tool. Ain Shames Science Bulletin, 28B, 389-406.

Tantawy, M.E., Hamed, K.A., EL-Magly, U.I. (2005) Floral morphology of some Taxa of Polygonaceae in Egypt. Journal of Biotechnology, 21, 308-329.

The Plantlist (2018) The PlantList.org [last retrieved 16.8.2018].

Van Leeuwen, P., Punt, W., Hoen, P.P. (1988) The northwest European pollen flora, 43. Review Palaeobotany and Palynology, 57, 81-151.

Wang, J.X., Feng, Z.J. (1994) A study of the pollen morphology of the genus Polygonum L., in China. Acta Phytotaxonomica Sinica, 32, 219-231.

Wodehouse, R.P. (1931) Pollen grains in the identification and classification of plants -6 . Polygonaceae. American Journal of Botany, 18, 749-764.

Yasmin, G., Khan, M.A., Shaheen, N., Hayat, M.Q.,Ali, S.,Abbas, S. (2010) Taxonomic implication of pollen morphology of seven species of Rumex L. from Pakistan. Pakistan Journal of Botany, 42(3), 1435-1442.

Yurtseva, O.V., Severova, E.E., Bovina, I.Yu (2014) Pollen morphology and taxonomy of Atraphaxis (polygoneae, Polygonaceae). Plant Systematic and Evolution, 300, 749-766.

Yurtseva, O.V., Kuznetsova, O.I., Mavrodieva, M.E., Mavrodiev, E.V. (2016) What is Atraphaxis L. (Polygonaceae, Polygoneae): Cryptic taxa and resolved taxonomic complexity instead of the formal lumping and the lack of morphological synapomorphies. Peer J, 4(3), e1977. Published online 2016 May 3. doi: 10.7717/peerj.1977

Zhang, X.P., Zhou, Z.Z. (1998) "A Study on Pollen Morphology and its Phylogeny of Polygonaceae in China". University of Science and Technology of China Press, Hefei. 
الشكل الخارجى لحبوب اللقاح والفصل بين الأجناس فى الفصيلـة الحمــــية فى مصر

$$
\text { منسى عادل شيحة العلوم البيولوجية و الجيولوجية ـ كلية التربية ـ جامعة الإسكندريـة ـ الإسكندريـةـ مصر. }
$$

تمت دراسـة الصفات الظاهرية الدقيقة لحبوب لقاح ثمانية عثر نوعا تتنمى إلى سبع أجناس من الفصيلة الحماضية بمصر بواسطة كلامن المجهر الضوئى والمجهر الماسح الالكترونى فى محاولة لإظهار قيمة هذه

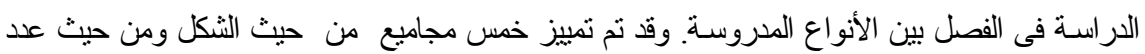
فتحات الأنبات بالإضافة إلى الزخرفة السطحية لحبوب اللقاح ـ وقد اتصفت المجموعة الأولى: بحبوب لقاح ثلاثية القتحات tricolporate و الزخرفة السطحية (striate- reticulate) و ميزة هذه المجموعة جنس

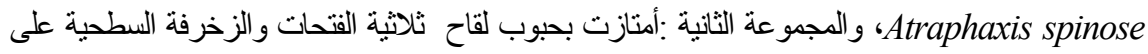

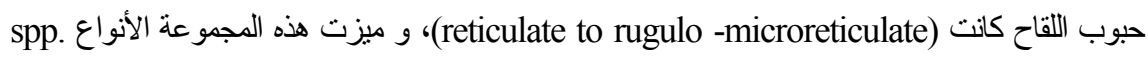
'pantoporate (Calligonum, Oxygonum sinuatum)

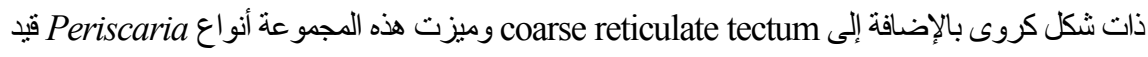

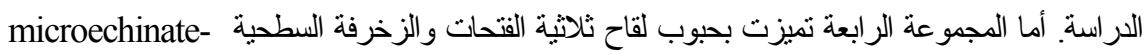

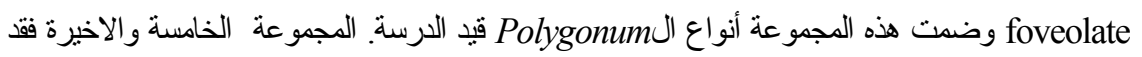

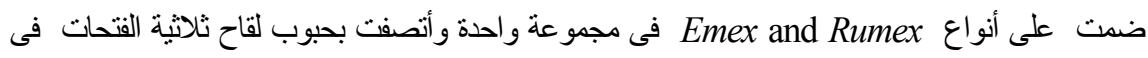
جنس Rumex بينما تميز جنس Emex بالإضافة إلى زخرفة لأسطح - brevicolpate granulate perforated tectum.

وقد أوضحت هذه الدراسة دور حبوب اللقاح فى الفصل بين الأنواع قيد الدراسة على مستوى النوع و الجنس. وقد أمكن من هذه الدر اسة تصميم مفتاح تعريفى للاجناس قيد الدراسة مستخذما أهم الصفات محل 